\title{
$\mathrm{M}|\mathrm{R}| \mathrm{S}$ Internet Journal Nitride Semiconductor Research
}

\section{The Durability of Various Crucible Materials for Aluminum Nitride Crystal Growth by Sublimation}

\author{
B. Liu ${ }^{1}$, J.H. Edgar ${ }^{1}$, Z. Gu ${ }^{1}$, D. Zhuang ${ }^{1}$, B. Raghothamachar ${ }^{2}$, M. Dudley ${ }^{2}$, A. Sarua ${ }^{3}$, Martin \\ Kuball $^{3}$ and H. M. Meyer III ${ }^{4}$ \\ ${ }^{1}$ Department of Chemical Engineering, Kansas State University, \\ ${ }^{2}$ Department of Materials Science Engineering, State University of New York at Stony Brook, \\ ${ }^{3}$ University of Bristol, $H$. H. Wills Physics Laboratory, \\ ${ }^{4}$ Oak Ridge National Laboratory, High Temperature Materials Laboratory,
}

(Received Monday, July 12, 2004; accepted Wednesday, October 20, 2004)

Producing high purity aluminum nitride crystals by the sublimation-recondensation technique is difficult due to the inherently reactive crystal growth environment, normally at temperature in excess of $2100{ }^{\circ} \mathrm{C}$. The durability of the furnace fixture materials (crucibles, retorts, etc.) at such a high temperature remains a critical problem. In the present study, the suitability of several refractory materials for AlN crystal growth is investigated, including tantalum carbide, niobium carbide, tungsten, graphite, and hot-pressed boron nitride. The thermal and chemical properties and performance of these materials in inert gas, as well as under AlN crystal growth conditions are discussed. TaC and $\mathrm{NbC}$ are the most stable crucible materials with very low elemental vapor pressures in the crystal growth system. Compared with refractory material coated graphite crucibles, HPBN crucible is better for AlN self-seeded growth, as crystals tend to nucleate in thin colorless platelets with low dislocation density.

\section{Introduction}

Aluminum nitride (AIN) is one of the most promising substrates for next generation high power, high frequency, and short wavelength optoelectronic devices based on gallium nitride $(\mathrm{GaN})$ and its alloys [1]. Its extraordinary physical, chemical, optical, and electrical properties make it attractive in III-nitride epitaxial film applications, as addressed elsewhere [2]. The benefits of AIN compared to sapphire or silicon carbide as a substrate for GaN-based devices include a reduced lattice constant mismatch hence lower defect densities and a reduced coefficient of thermal expansion mismatch thus lower thermal stress. Because the structure of AlN is identical to GaN, epitaxial films can be grown on all crystal orientations, not just the (0001) plane. This may eliminate polarization effects and improve the quantum efficiency of nitride semiconductor LEDs and laser diodes. AlN will not alter the charge carrier background concentration in eptiaxial films by diffusion or autodoping as it is composed of only group III and group V elements that are isoelectronic with GaN. The properties of AlN even more closely match those of high Al mole fraction AlGaN epitaxial layers, which are necessary for the fabrication of deep ultraviolet (DUV) optoelectronic devices [3] [4]. The initial reports on transistors and LEDs using AlN substrates demonstrate its promising characteristics [5] [6]. In short, using AlN substrates should significantly improve the power density, efficiency, lifetime, and reliability of GaN-based devices.

Currently, several groups are producing bulk AlN crystals by the sublimation-recondensation technique [1] [5] [7] [8]. To achieve good quality bulk AlN single crystals with fast growth rates $(>200 \mu \mathrm{m} / \mathrm{h})$, high temperatures, above $2100{ }^{\circ} \mathrm{C}$, are required. At such high temperatures, the crucible and furnace fixture components are no longer passive, as their vapor pressure may be significant, or they may react with the source materials (AlN powder and nitrogen). The presence of elements from the crucible material may alter the AlN crystal habit by changing the fastest growth direction. Incorporation of impurities from the crucible into the crystal may cause stress or defects. In this paper, attention is focused on the durability and performance of several refractory crucible materials. The most probable species present in the vapor phase and their vapor pressures in the crystal growth system are discussed from 
the results of thermodynamic analysis. The performance of those crucible materials under the crystal growth conditions is addressed as well.

\section{Background}

Almost all early works of AlN crystal growth in the 1960s and 1970s employed graphite crucibles [9] [10] [11] [12] [13] [14] [15] [16] [17], but carbon contamination was significant. Horiuchi and co-workers [18] produced kite-shape twined AlN crystals by using graphite crucibles. Dark particles were attached to the corner of crystals. They suggested that $\mathrm{Al}_{2} \mathrm{OC}$ might be partly formed in the crystal structure of AIN [14]. To suppress carbon contamination, $\mathrm{SiC}$ coated graphite crucibles were employed [19] [20] [21]. Carbon containing precipitates were avoided and kite shaped crystals were no longer observed, but the coating eventually degraded, because of sublimation of the SiC coating and the diffusion of aluminum through the $\mathrm{SiC}$ barrier, reacting with the graphite and causing the coating to spall.

To avoid carbon contamination, Slack and McNelly [22] [23], as well as other researchers [5] [8] [24], chose tungsten for crucibles due to its high melting point and resistance to attack by $\mathrm{Al}$ vapor up to $2275^{\circ} \mathrm{C}$ under $1 \mathrm{~atm}$ of nitrogen [23]. Relatively large AlN (up to $15 \mathrm{~mm}$ in diameter) crystals have been grown in tungsten crucibles. At extremely high temperatures (2330 ${ }^{\circ} \mathrm{C}$ ) the crucibles eventually failed when pinholes form at the tungsten grain boundaries. Schowalter and Slack [25] speculated that this was due to aluminum dissolving into the tungsten (approximately $5.3 \mathrm{wt} \%$ ), causing the lattice constant of the tungsten to shrink and the grains to separate. Eliminating spurious polycrystalline growth, cracking, and the presence of highly strained regions [26] are all major concerns with tungsten as the crucible.

Boron nitride is another choice for crucible material [27] in AlN crystal growth. BN does not wet or react with either $\mathrm{Al}$ or nitrogen, and hot-pressed boron nitride (HPBN) is easy to machine. Our research group obtained clear and colorless thin platelets up to $60 \mathrm{~mm}^{2}$ in HPBN crucible [28].

To date, there has been no systematic investigation of the effects the furnace fixture materials on both the crystal growth process and final properties of the AlN crystals. Materials suitable for bulk AlN crystal growth must have the following properties:

1. The material must have a melting point in excess of $2300{ }^{\circ} \mathrm{C}$;

2. it must not form low melting temperature eutectics with $\mathrm{Al}, \mathrm{N}$, or the heating elements of the furnace (typically, graphite or tungsten);
3. it should not react with $\mathrm{Al}$ vapor, $\mathrm{N}_{2}$, or the heating elements, or the reaction should be self-limited;

4. its vapor pressure should be relatively low compared to that of $\mathrm{Al}$ and $\mathrm{N}_{2}$ over AlN.

In practical terms, the crucible material should not contain oxygen, because the great affinity of aluminum for oxygen makes these two elements very likely to react. This set of criteria suggests that potential candidates are limited to several pure refractory metals (W, Ta, $\mathrm{Nb}$, and Hf), refractory carbides, nitrides, and borides.

Table 1 summarized the reactivity of these materials as reported in the literature, all of which have melting points higher than $2600{ }^{\circ} \mathrm{C}$, excellent high-temperature strength, and good corrosion resistance. Aluminum reacts with transition-metal carbides and nitrides films only to a limited extent, and created pinholes into the films [29]. However, $\mathrm{TaC}$ and $\mathrm{TiC}$ particles have high stability and uniform distribution in molten $\mathrm{Al}$ up to $1000{ }^{\circ} \mathrm{C}$ [30]. From calculation [31], the relative tendencies of these compounds to react with molten $\mathrm{Al}$ were $\mathrm{HfC}<\mathrm{TaC}<\mathrm{NbC}<\mathrm{TiC}<\mathrm{WC}$, and $\mathrm{TaN}<\mathrm{TiN}$. Yet, there are no reports in the literature discussing the reactions between $\mathrm{Al}$ vapor and refractory carbides and nitrides in a carbon and nitrogen rich environment, i.e. in a resistively heated graphite furnace.

In the following sections, the performance and effects of several materials on AlN crystal growth are reported. First thermodynamic calculations were made to predict the vapor pressures of the candidate materials. Next, the candidate crucible materials were tested in two furnaces with different heating elements: one used tungsten, the other graphite. Tungsten crucibles were used in the tungsten furnace, since the reaction between tungsten and graphite at the temperature range from $1400{ }^{\circ} \mathrm{C}$ to $1800^{\circ} \mathrm{C}$ will seriously harm the crucible and the crystal growth process. Similarly, BN crucible can only be used in a graphite furnace because early studies by our group showed $\mathrm{BN}$ crucibles react with tungsten. At the crystal growth temperature, pure refractory metals will react with the carbon and/or nitrogen in graphite furnace under nitrogen ambient. Thus, only some refractory carbides/nitrides might be considered as candidate materials in graphite system.

\section{Thermodynamic Calculations}

This section discusses the vapor pressure of refractory metals over solid materials from thermodynamic calculations. Calculations were made for the most probable species present in the system under the crystal growth conditions. Predictions were also made on the crucible materials that fulfilled all four requirements. The lower the vapor pressure of a species, the less the tendency there is for its elements to incorporate into the AlN crystals. 
The equilibrium vapor pressures were calculated from Joint-Army-Navy-Air Force (JANAF) thermodynamic data [32] by STANJAN, written by W. Reynolds of Stanford, using minimization of the total Gibbs free energy. Over the temperature range from $1700{ }^{\circ} \mathrm{C}$ to $2600{ }^{\circ} \mathrm{C}$, the equilibrium vapor pressures were calculated for two different situations: for pure refractory metals in equilibrium with their solids under 1 atmosphere of an inert gas, i.e. argon; and for the refractory metal in equilibrium with its solid-state nitride and/or carbide in the presence of graphite and 1 atmosphere of nitrogen. The later simulated the conditions of the graphite furnace. The vapor pressures of $\mathrm{C}, \mathrm{Nb}, \mathrm{Ta}$, and $\mathrm{W}$ over their solids at the first equilibrium are plotted in figure 1. The vapor pressure of Ti over solid titanium diboride under $1 \mathrm{~atm}$ of inert gas is also included in figure $1 . \mathrm{Nb}, \mathrm{Ta}$, and $\mathrm{W}$ each have a lower vapor pressure than carbon within the temperature range from $1700{ }^{\circ} \mathrm{C}$ to $2600^{\circ} \mathrm{C}$. Table 2 lists the presumed species present in the vapor phase and solid phase under the second equilibrium for each candidate, and the calculated molar ratio of carbide over the total of carbide and nitride. In the second situation, we calculated the vapor pressure of $\mathrm{Al}, \mathrm{B}, \mathrm{Ti}, \mathrm{Nb}, \mathrm{W}$, and $\mathrm{Ta}$ over their carbide and/or nitride. Figure 2 shows the calculated equilibrium vapor pressure for candidate crucible material in graphite system under the second situation, as well as $\mathrm{Al}$ vapor over AlN. B and Ti have much higher vapor pressure than $\mathrm{Nb}, \mathrm{W}$, and Ta, where Ta has the lowest vapor pressure in this graphite system.

From these calculations, the following conclusions may be drawn.

1. BN will not convert to boron carbide;

2. $\mathrm{TaC}$ and $\mathrm{NbC}$ exist stably in the system with very little tendency to form nitrides;

3. TiC will transform into a mixture of carbide and nitride, with carbide dominating as temperature increases;

4. W will react with graphite and form WC.

From the thermodynamic calculations of those candidate materials, we predict that $\mathrm{TaC}$ and $\mathrm{NbC}$ are the most stable crucible materials with very low elemental vapor pressure in a graphite furnace under the crystal growth conditions.

\section{Crystal growth}

\subsection{Experimental procedure and characterization}

In the crystal growth process, the reaction $\mathrm{AlN}(\mathrm{s}) \leftrightarrow \mathrm{Al}$ (v) $+1 / 2 \mathrm{~N}_{2}$ is driven in the forward direction at the source material, and in the reverse direction at the crystal growth zone by a slight reduction in temperature. The source material was AlN powder with elemental analysis of $\mathrm{O}$ less then $0.9 \mathrm{wt} \%$ and $\mathrm{C}$ less than 0.04 wt $\%$. Tungsten crucible was used in tungsten furnace. All other candidate crucibles, including $\mathrm{TaC}, \mathrm{NbC}$, HPBN, and graphite, were used in graphite furnace.

The AlN crystals were grown between $1800{ }^{\circ} \mathrm{C}$ and $2200{ }^{\circ} \mathrm{C}$. Ultra high purity nitrogen continuously flowed through the system at 800 torr to prevent the heating element from reacting with trace oxygen. The growth environment was always nitrogen-rich as the nitrogen pressure is orders of magnitude higher than the saturation vapor pressure of nitrogen over AlN, which is less than $9.9 \times 10^{-3} \mathrm{~atm}$ at the growth temperature range [23]. The temperature difference between the source zone, where AlN source sublimes, and the growth zone, where $\mathrm{Al}$ and nitrogen recondense, was less than $10{ }^{\circ} \mathrm{C}$ as determined by the premeasured temperature profile.

Macrostructure features of the as-grown AlN crystals were characterized by optical microscopy at magnifications of 10-200X. Micro-Raman spectra were obtained using a Renishaw UV micro-Raman system with the $325 \mathrm{~nm}$ line of a $\mathrm{HeCd}$ laser as the excitation source. The spot size and the spectral resolution were 1$2 \mu \mathrm{m}$ and $3-4 \mathrm{~cm}^{-1}$, respectively. X-ray topographies were taken at the Stony Brook Synchrotron Topography Station. Topographies were recorded on 8 " $\times 10$ " Kodak Industrex SR-45-1 high-resolution X-ray film.

\subsection{Growth of AIN in TaC coated graphite crucible}

For the first time, TaC coated graphite crucible was employed in bulk AlN crystal growth. Amber colored AlN crystals were produced in a $\mathrm{TaC}$ coated graphite crucible at $2074{ }^{\circ} \mathrm{C}$ and 805 torr for 24 hours. The AlN crystals nucleated in high density on the $\mathrm{TaC}$, and grew into a polycrystalline mass. The phonon frequency of E2(high) mode and A1(TO) mode from Raman characterization are $655 \mathrm{~cm}^{-1}$ and $612 \mathrm{~cm}^{-1}$, with line widths are $7 \mathrm{~cm}^{-1}$ and $15 \mathrm{~cm}^{-1}$ respectively, indicating the AlN crystal's high quality. However, since the AlN wetted with $\mathrm{TaC}$, it was very difficult to separate the crystals from the nucleation surface. A scanning Auger microscopy (SAM) line scan on the cross-sectional area of the $\mathrm{TaC}$ foil with AlN crystal shows that the $\mathrm{TaC}$ foil lose carbon and pick up small amount of nitrogen (figure 3). Although the $\mathrm{TaC}$ film has good process durability and good crystal nucleation characteristics, pinholes in the coating lead to the reactions between the $\mathrm{Al}$ vapor and underlying graphite, and cause the coating to spall off.

\subsection{Growth of AIN in NbC coated graphite crucible}

Prism shaped AlN needles and hexagonal hillocks of millimeter size crystals were grown on the nucleation surface with high nucleation density. However, NbC coated graphite crucibles suffered from the same pinhole problem as TaC coated crucibles. SAM characterization shows the $\mathrm{NbC}$ coating is stable against $\mathrm{Al}$, and 
nitrogen is detected from the damaged $\mathrm{NbC}$ coating, primarily at the grain boundaries and not in the bulk $\mathrm{NbC}$. From selective etching analysis in $45 \mathrm{wt} \% \mathrm{KOH}$ solution, we infer that freely nucleated crystals predominately have the nitrogen to aluminum direction pointing out from the nucleation surface, which means that the ends of the AlN crystals facing the source are aluminum polarity [33].

\subsection{Growth of AIN in tungsten crucible}

Typically, amber colored AlN crystals are produced in tungsten crucibles with a high nucleation density in a three-dimensional growth mode. Sliced and polished AlN crystals grown in $\mathrm{W}$ crucible have grain size about $0.5 \mathrm{~mm} \times 0.5 \mathrm{~mm}$ (Figure 4). The growth temperature was about $2000{ }^{\circ} \mathrm{C}$ and growth time was 14 hours. Due to a high nucleation density, it was hard to get single crystalline seeds from this kind of samples for the subsequent seeded growth. The crystals grown in tungsten crucible contain no intentional impurities, but $\mathrm{W}$ and $\mathrm{O}$ are inherited from the crucible and source material. Neutron activation analysis revealed 0.2 to $4.6 \mathrm{ppm}$ wt $\mathrm{W}$ in the grown crystals, lower than the $7.9 \mathrm{ppm}$ wt reported by Bickermann [8]. However, combustion analysis shows an average value of $500 \mathrm{ppm}$ wt $\mathrm{O}$ in the grown crystals, which is higher than the $86 \mathrm{ppm}$ wt from Bickermann's result [8]. There is no reaction between the tungsten furnace fixtures and nitrogen under the growth condition, thus no tungsten nitride, which decomposes at temperature less than $800{ }^{\circ} \mathrm{C}$ [34], formed during AlN crystal growth.

\subsection{Growth of AIN in graphite crucible}

Growth in graphite crucibles consistently produces needles and kite-shaped twinned crystals bounded on edges along the $\mathrm{c}$ direction. These platelets are transparent and colorless m-plane (1100) crystals with very flat surface morphology. The corner with the smallest angle $\left(60^{\circ}\right)$ is where the crystal was in contact with the graphite crucible and hence is the initial point where the crystals began to grow. Dark particles are usually attached to this corner, and these m-plane crystals do not etch in molten $\mathrm{KOH}$ solution. A thorough discussion of this type of twin can be found in reference [18]. Graphite has good process durability below $2050{ }^{\circ} \mathrm{C}$, but carbon causes the AlN crystals to twin. At the crystal growth temperature of $2100{ }^{\circ} \mathrm{C}$ and $1 \mathrm{~atm}$ of nitrogen, the calculated carbon vapor pressure is in the order of $10^{-8} \mathrm{~atm}$. However, cyanogen $(\mathrm{CN})$ has an even higher partial pressure of $10^{-5} \mathrm{~atm}$, which will always be significant in a graphite furnace at the temperatures typical for AlN crystal growth. Thus, there is a high potential for carbon to incorporate into AlN crystals, and cyanogen is more likely the main transport agent for carbon than elemen- tal carbon. In AlN crystals, $\mathrm{C}$ can substitute $\mathrm{N}$ and create specific defects, such as stacking faults and inversion domains. $\mathrm{Al}_{4} \mathrm{C}_{3}$ will also form from reaction between graphite and $\mathrm{Al}$ vapor, or $\mathrm{Al}_{2} \mathrm{CO}$ if there is any trace oxygen in the system. Figure 5 shows the needle and kite shape AlN crystals with graphite contamination grown in a graphite crucible under $1800{ }^{\circ} \mathrm{C}, 800$ torr for 48 hours.

\subsection{Growth of AIN in HPBN crucible}

Hot pressed boron nitride (HPBN), pyrolytic boron nitride $(\mathrm{pBN})$ and a titanium diboride/BN composite $\left(60 \% \mathrm{TiB}_{2}, 40 \% \mathrm{BN}\right)$, were investigated as crucible materials for bulk AlN crystal growth. Only AlN needles were obtained in $\mathrm{TiB}_{2} / \mathrm{BN}$ crucibles under the typical crystal growth condition. The pBN crucible began to form pits on the crucible wall at a temperature about $1800{ }^{\circ} \mathrm{C}$. At higher temperatures, the crucible wall began to peel until it finally failed. The HPBN crucible was the most durable crucible of these three boronbased crucibles. Although the HPBN crucible encountered mass loss each run, which is less than $0.30 \mathrm{wt} \%$ per hour, a crucible with $2 \mathrm{~mm}$ wall thickness can survive several hundred of hours under the growth conditions.

Clear and colorless AlN platelets up to $60 \mathrm{~mm}^{2}$ were prepared in HPBN crucibles by sublimation-recondensation technique under $2100{ }^{\circ} \mathrm{C}, 800$ torr for 48 hours (Figure 6). Crystals grown in HPBN crucibles typically form thin platelets with the fastest growth rate above $400 \mu \mathrm{m} / \mathrm{hr}$ occurring in the c-axis direction. In the adirection, the growth rate is much lower, about $50 \mu \mathrm{m} / \mathrm{hr}$ under the same growth condition. Growth striations run the length of the crystals in the c-direction, the cause of which has not been identified. In contrast to the other crucible materials employed in this study, the AlN nucleation density was relatively low on HPBN, and the crystals did not agglomerate together to form a dense polycrystalline mass. Instead, it was highly porous. Figure 7 shows the Raman spectrum for AlN crystals grown in HPBN crucibles. There is no significant difference in phonon frequency between sample with and without striations. The phonon frequency of E2 (high) mode and A1 (TO) mode from Raman characterization for both samples are $655 \mathrm{~cm}^{-1}$ and $609 \mathrm{~cm}^{-1}$. Line widths for both modes are $6 \mathrm{~cm}^{-1}$, which indicates good crystal quality. X-ray topography reveals numerous crystallites concentrate in some regions on the sample surface (figure 8). Crystallites are also scattered in some other regions. The crystallites induce strains and sometimes cracking on the surface, as evident in the x-ray topography. A few inclusions (I) are also observed. This sample appears essentially dislocation-free. However, from 
thermodynamic calculations, vapor pressure of B over $\mathrm{BN}$ in graphite furnace is very high among all the candidate crucible materials under the crystal growth condition, which is $3.5 \times 10^{-7} \mathrm{~atm}$.

\section{Conclusions and future work}

1. Graphite, silicon carbide, and titanium diboride either react with aluminum or sublime at typical crystal growth temperatures. Consequently, none of these materials are suitable as crucible materials.

2. Pure tungsten is a very durable crucible material for AlN crystal growth. However, AlN crystals nucleated together in a high density making it difficult to obtain good quality single crystals in tungsten crucibles.

3. Both $\mathrm{TaC}$ and $\mathrm{NbC}$ are very good candidate crucible materials, as they are compatible with graphite components, have low metal vapor pressures, and do not react with either nitrogen or aluminum. But the machining of both sintered $\mathrm{TaC}$ and $\mathrm{NbC}$ is difficult, and the costs of these materials are high. These significantly restrain their use as crucible materials. New procedures for producing the carbides from the metals may solve this problem. Coated graphite components are not suitable for AlN crystal growth, as the coatings tend to spall off.

4. Compared with $\mathrm{TaC}$ or $\mathrm{NbC}$ coated graphite, HPBN is a better crucible material for AlN self-seeding growth, as crystals tend to nucleate in a relatively low density and do not merge together. Unfortunately, it difficult to produce large crystals in HPBN crucibles, and the crystals produced are highly striated.

\section{ACKNOWLEDGMENTS}

We are grateful for the support of this research from BMDO (Contract No: N00014-98-C-0407), ONR (Contract No. N00014-99-1-0104), and the Assistant Secretary for Energy Efficiency and Renewable Energy, Office of Transportation Technologies, as part of the High Temperature Materials Laboratory User Program, Oak Ridge National Laboratory. Oak Ridge National Laboratory is managed by UTBattelle, LLC, for the U.S. Department of Energy under contract number DE-AC05-00OR22725.

\section{REFERENCES}

[1] J. H. Edgar, L. Liu, B. Liu, D. Zhuang, J. Chaundhuri, M. Kuball, S. Rajasingam, J. Cryst. Growth 246, 187-193 (2002).

[2] J.H. Edgar, S.Strite, I.Akasaki, H.Amano, C.Wetzel, Properties, processing and applications of $G a N$ and related semiconductors, (INSPEC, Institution of Electrical Engineers, London, UK, 1999), .
[3] S.P. DenBaars, A. Hanlon, T.M. Katona, M. Pattison, J. Kaeding, R. Sharma, M.C. Schmidt, T. Margalith, C. Moe, S. Keller, P. Cantu, T. Li and N. Nakamura, "AlGaN Based UV Light Emitting Diodes and Photodetectors", in Program and Abstracts of NATO Advanced Research Workshop"UV SolidState Light Emitters and Detectors", (2003)

[4] R. Gaska, A. Khan and M.S. Shur, "Epitaxial AlGaN Layers for UV LEDs on Sapphire and Bulk AlN", in Program and Abstracts of NATO Advanced Research Workshop "UV Solid-State Light Emitters and Detectors", (2003)

[5] J. Carlos Rojo, L. J. Schowalter, R. Gaska, M. Shur, M. A. Khan, J. Yang, D. D. Koleske, J. Cryst. Growth 240, 508 (2002).

[6] G. Slack, J. Carlos Rojo, L. J. Schowalter, K. Morgan, J. Barani, S. Schujman, S. Biswas, B. Raghothamachar, M. Dudley, M. Shur, R. Gaska, N. M. Johnson, M. Kneissl, Mater. Res. Soc. Symp. Proc. 722, 5 (2002).

[7] Raoul Schlesser, Rafael Dalmau, Rositza Yakimova, Zlatko Sitar, Mater. Res. Soc. Symp. Proc. 693, I9.4.1 (2002).

[8] M. Bickermann, B.M. Epelbaum and A. Winnacker, "PVT growth of bulk AlN crystals with low oxygen contamination”, Phys. Stat. Sol. C, 1993 (2003)

[9] G. A. Cox, D. O. Cummins, K. Kawabe, R. H. Tredgold, J. Phys. Chem. Sol. 28, 543 (1967).

[10] R. F. Rutz, Appl. Phys. Lett. 28, 379 (1976).

[11] J. A. Kohn, P. G. Cotter, R. A. Potter, Am. Miner. 41, 355 (1956).

[12] J. Pastrnak, L. Roskovcova, Phys. Stat. Sol. 7, 331 (1964).

[13] B. Krukowska-Fulde, T. Niemyski, Electron Tech. 3, 3 (1970).

[14] T. Ishii, T. Sato, M. Iwata, Miner. J. 8, 1 (1975).

[15] H. D. Witzke, Phys. Stat. Sol. 2, 1109 (1962).

[16] Philips Electronic and Associated Industries, Ltd., Patent Country: GB; Priority Application Country: NL GB 1196029; US 3634149, 0624; Priority Application Date: 19661025, 1970

[17] K. Kwabe, R.H. Tredgold and Y. Inuishi, "Electrical and Optical properties of AlN_a Thermostable Semiconductor", Electr. Eng. Jpn. 87, 62 (1967)

[18] S. Horiuchi, T. Ishii, K. Asakura, J. Cryst. Growth 21, 17 (1974).

[19] C. M. Balkas, Z. Sitar, T. Zheleva, L. Bergman, R. Nemanich, R. F. Davis, J. Cryst. Growth 179, 363 (1997).

[20] CM Balkas, Z Sitar, T Zheleva, L Bergman, IK Shmagin, JF Muth, R Kolbas, R Nemanich, RF Davis, Mater. Res. Soc. Symp. Proc. 449, 41-46 (1997).

[21] T.K. Hossain, J.V. Lindesay and M.G. Spencer, "Growth and Characterization of Bulk Aluminum Nitride by Physical Vapor Transport", arXiv.org e-Print: Condensed Matter, 0204297(2002).

[22] G. A. Slack, T. F. McNelly, J. Cryst. Growth 42, 560 (1977).

[23] G. A. Slack, T. F. McNelly, J. Cryst. Growth 34, 263 (1976).

[24] Y. Shi, B. Liu, L. Liu, J. H. Edgar, H. M. Meyer III, E. D. Payzant, L. R. Walker, N. D. Evans, J. G. Swadener, J. Chaudhuri, Joy Chaudhuri, Phys. Stat. Sol. A 188, 757 (2001). 
[25] L.J. Schowalter and G.A. Slack, Patent Application Country: Application: US; Patent Country: US; Priority Application Country: US 2003127044, 0710; Patent Application Date: 20020920.; Priority Application Date: 20010921, 2003

[26] J. Carlos Rojo, L. J. Schowalter, K. Morgan, D. I. Florescu, F. H. Pollak, B. Raghothamachar, M. Dudley, Mater. Res. Soc. Symp. Proc. 680E, E2.1 (2001).

[27] R. Schlesser, Z. Sitar, J. Cryst. Growth 234, 349 (2002).

[28] B. Liu, J.H. Edgar, B. Raghothamachar, M. Dudley, J.

Lin, H. Jiang, A. Sarua and M. Kuball, "Free Nucleation of

Aluminum Nitride Single Crystal in HPBN Crucible by Sublimation", Mater. Sci. Eng. B (accepted)

[29] M. Wittmer, J. Appl. Phys. 53, 1007 (1982).

[30] M. Kobashi, M. Harata and T. Chioh, "Dispersion behavior of several carbides into molten aluminum and mechanical properties of TiC/Al composites", Keikinzoku J Jpn Inst Light Met 43, 522 (1993)

[31] G. Kaptay, S.N. Akhmedov and Y.V. Borisoglebskii, "Thermodynamic evaluation of the reactions of metal-like refractory compounds with molten aluminum", Tsvetnaya Metallurgiya 6, 70 (1988)

[32] D.R. Stull, H. Prophet, JANAF thermochemical tables, (NSRDS-NBS 37, Washington, 1971), .

[33] D. Zhuang, J.H. Edgar, Lianghong Liu, B. Liu, L. Walker, MRS Internet J. Nitride Semicond. Res. 7, 4 (2002).

[34] L.E. Toth, "Transition Metal Carbides and Nitrides", Academic, New York, 1971

[35] T. Sata, T. Urano, J. Ceram. Soc. Jap. 78, 21 (1970).

[36] G. A. Slack, Mater. Res. Soc. Symp. Proc. 512, 35 (1998).
[37] E.K. Storms, "The Refractory Carbides (Refractory Materials, Vol. 2) ", Academic, New York, 1967

[38] I. Y. Konyashin, V. I. Kostikov, I. V. Naramovskii, Zh. Fiz. Kh. 59, 418 (1985).

[39] K. I. Portnoi, Y. V. Levinskii, Zh. Fiz. Kh. 37, 2467 (1963).

[40] B.P. Kuz'min, L.I. Kvater and I.V. Frishberg, "Materials for High-Temperature Vacuum Evaporation of Aluminum", Tsvetnye Metally, 48, 68 (1975)

[41] B. Y. Shew, J. L. Huang, Mater. Sci. Eng. A a159, 127 (1992).

[42] A.L. Burykina and T.M. Evtushok, "The study of contact interaction between metal-like borides and graphite at high temperatures in vacuo", Poroshkovaya Met. 5, 75 (1965)

[43] G.V. Samsonov and L.V. Strashinskaya, "Surface reactions in solid phases of borides with high-melting metals and $\mathrm{ZrO}_{2}$ ", Vysokotemp.Neorgan.Soedin. 437 (1965)

[44] T. Kubota, J. Nucl. Sci. Technol. 4, 582 (1967).

[45] A. Schneider, R. Gehrke, M. Kretschmer and M. Wassermann, "Sintering Behavior and Reaction Characteristics of Titanium Carbice, Titanium Nitride, and Boron Nitride", Metall 23(3), 230 (1969)

[46] A.L. Burykina and T.M. Evtushok, "Graphite and pyrolytic graphite reactions with titanium and zirconium nitrides”, Poroshkovaya Metallurgiya 9(5), 51 (1969)

[47] C.W. Le Maistre, "High temperature reactions in the system tantalum carbide-titanium nitride-tungsten, tantalum carbide-zirconium nitride-tungsten, and tantalum carbidehafnium nitride-tungsten", Weapons Res. Estab. Rep., WRECPD-141, 47 (1968) 


\section{FIGURES}

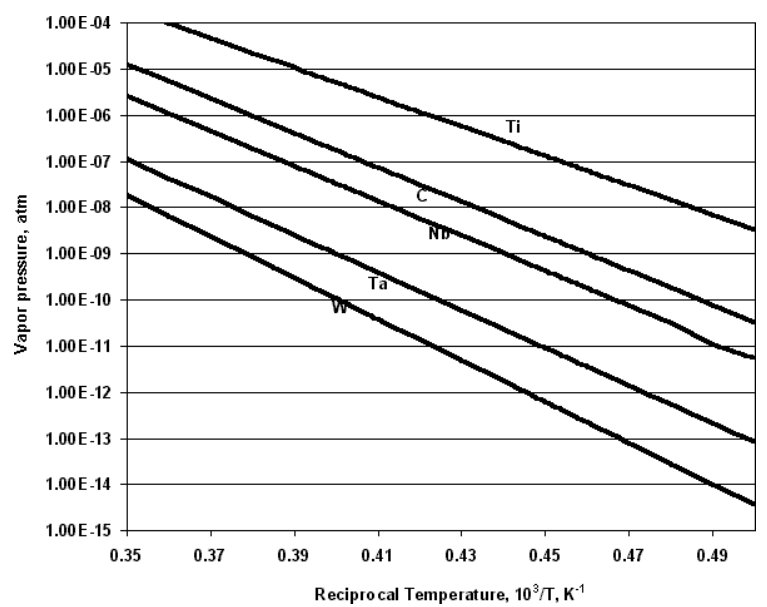

Figure 1. Pure metal vapor pressure over metal solid at 1 atmosphere of inert gas.

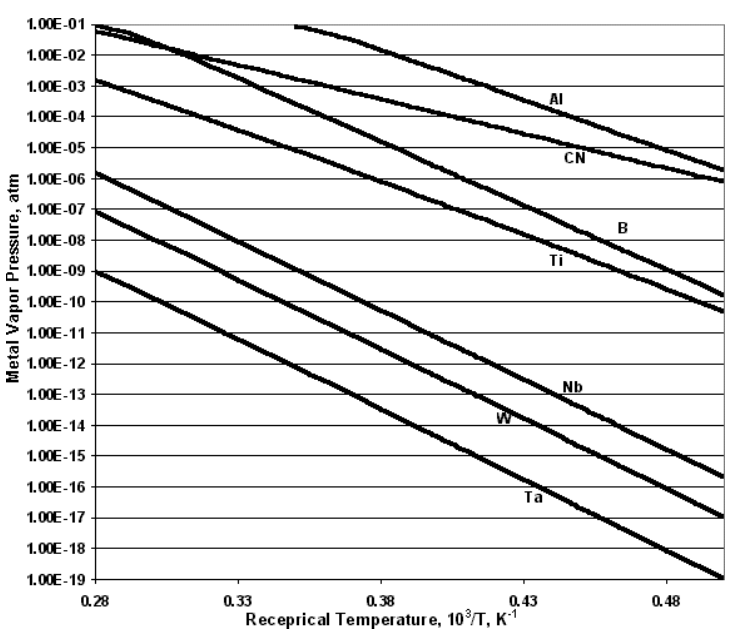

Figure 2. Refractory metal vapor pressure over their carbides and/or nitrides in graphite furnace system at 1 atmosphere of nitrogen. 


\begin{tabular}{|c|c|c|}
\hline je:2127.in:AN/TaC Foil (ex-situ tach re) & & ORNL-ATMML \\
\hline O2 Doe $12100 \mathrm{ko} / \mathrm{l}$ O FR.R & $2.64420+001 \mathrm{max}$ & \\
\hline Na2/Ful (Nom ino) & & \\
\hline
\end{tabular}

e1212.7.lis

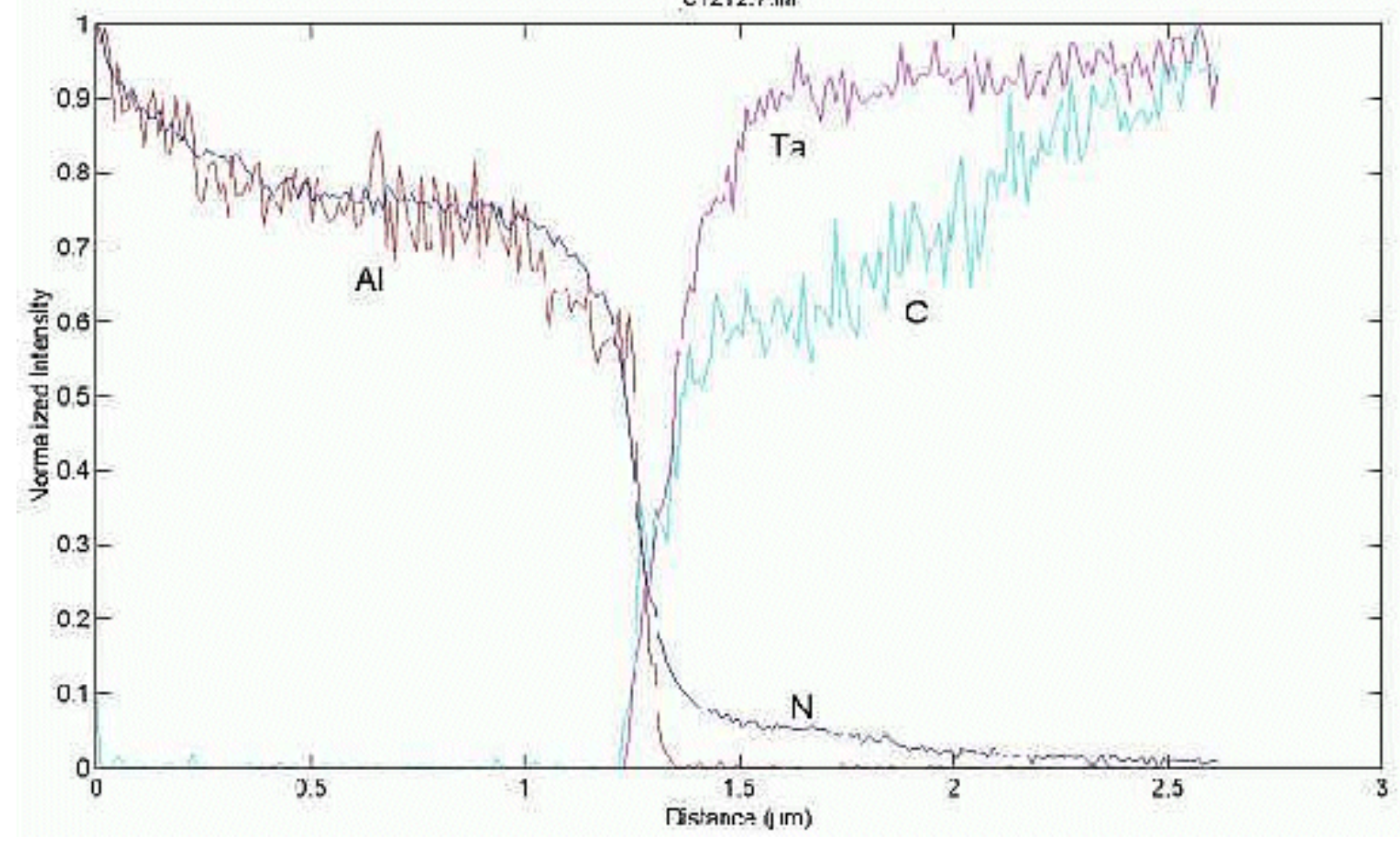

Figure 3. Line scan of the cross-sectional area of TaC foil with AlN crystal showing N "segregation" and C "depletion". 


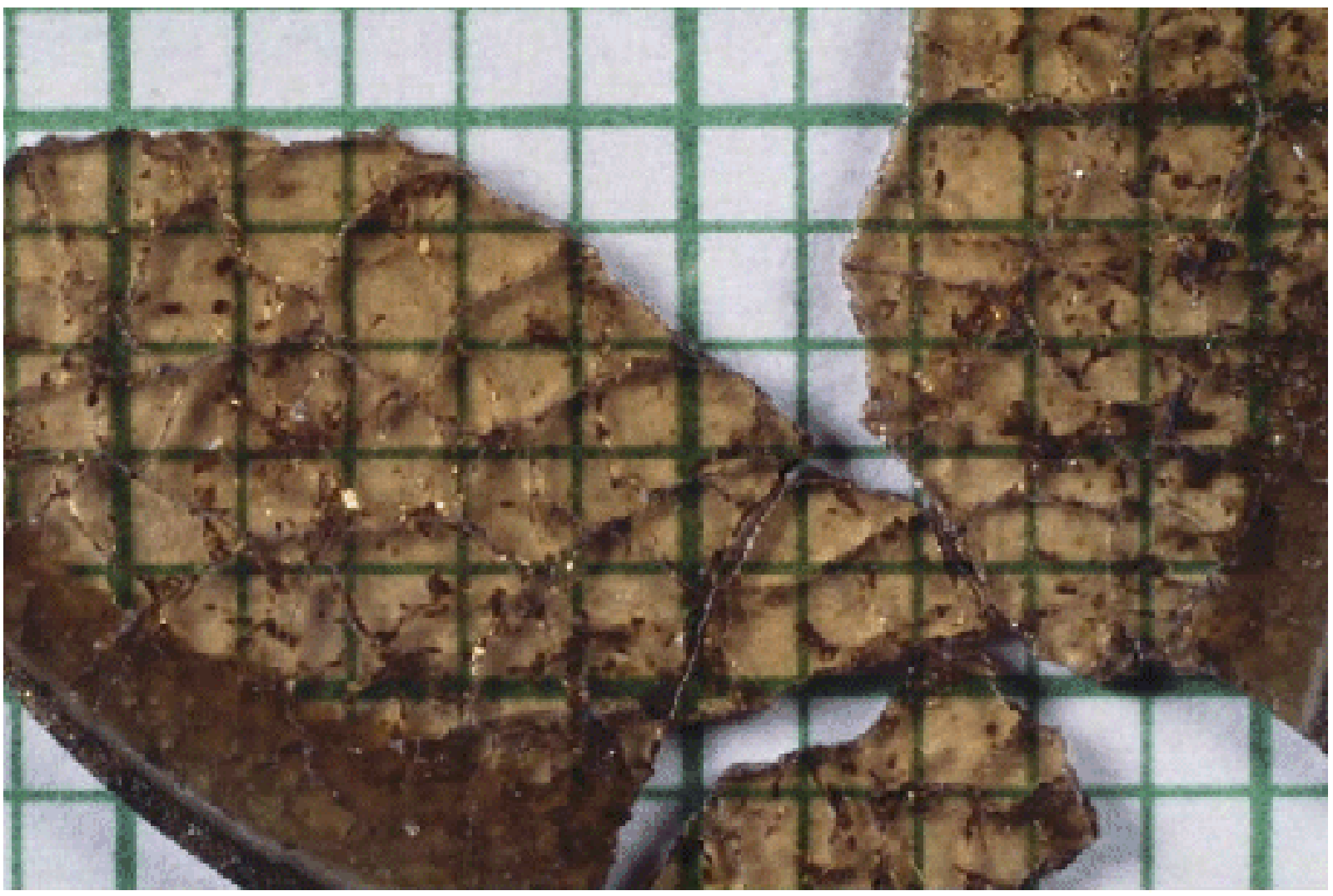

Figure 4. Sliced and polished AlN crystal grown in tungsten crucible.

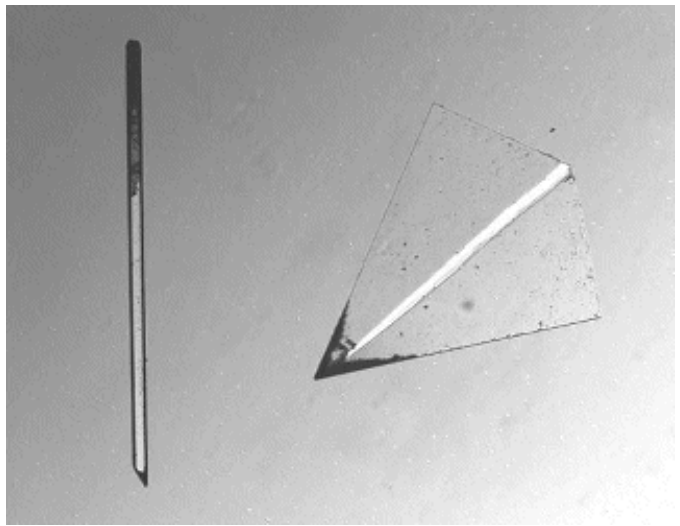

Figure 5. Needle and kite-shape AlN crystals grown in graphite crucible. 


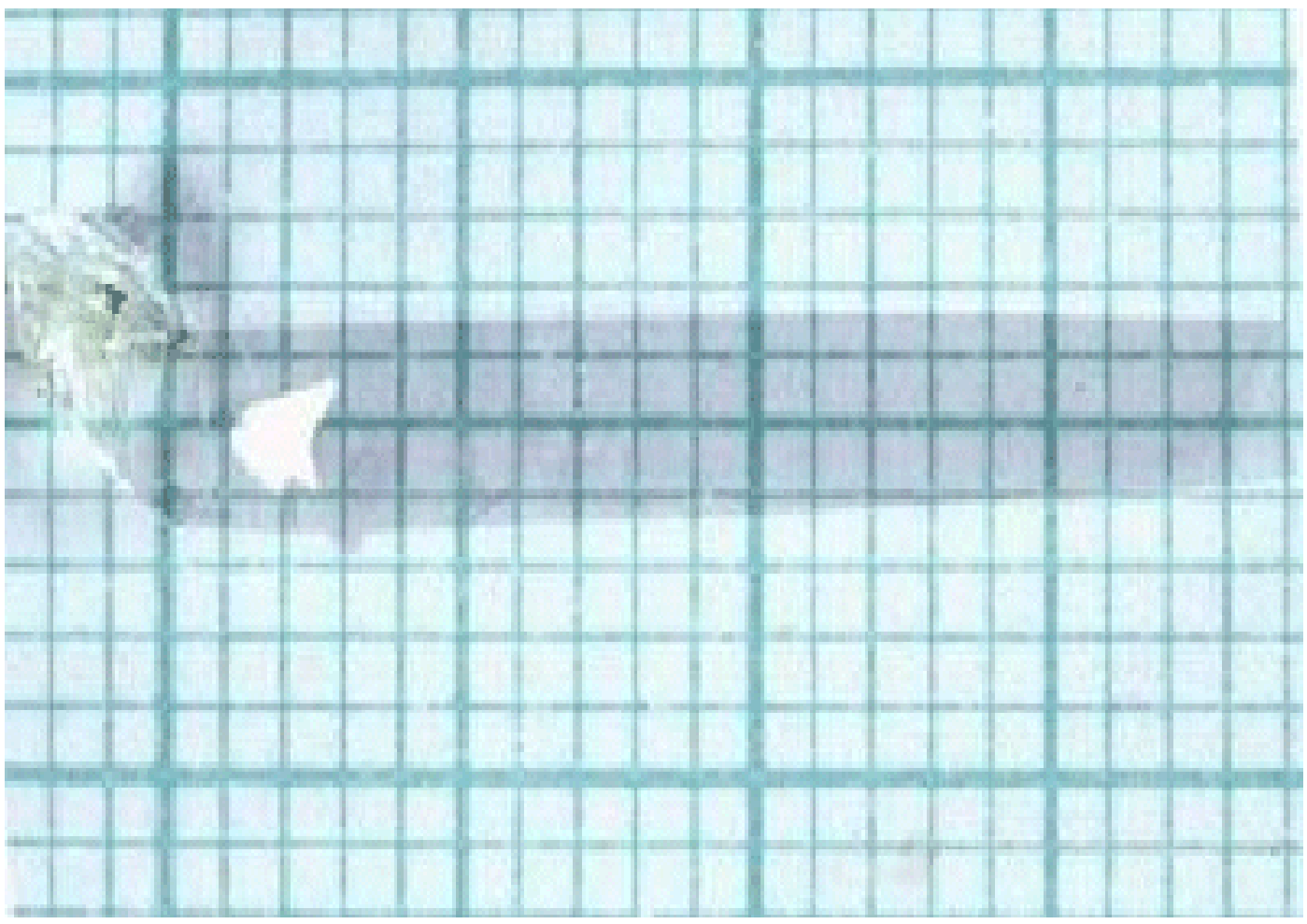

Figure 6. AlN crystal produced in HPBN crucible up to $60 \mathrm{~mm}^{2}$.
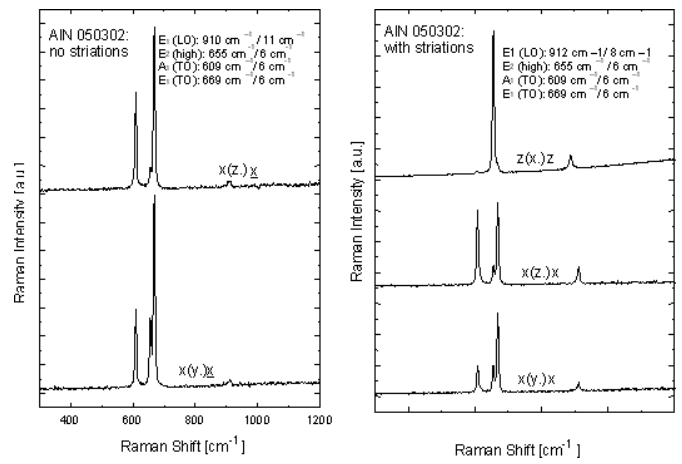

Figure 7. Raman spectrum for AIN crystal as seen in figure 6.

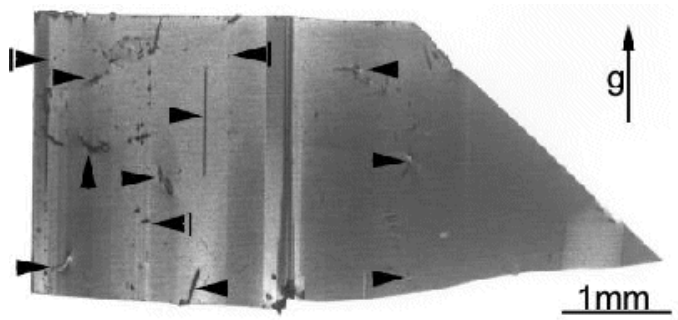

Figure 8. Transmission topograph $(\mathrm{g}=0002, \lambda=0.69 \AA)$ showing inclusions (I). Arrow marks indicate contrast from surface artifacts such as ridges, scratches, strains, and cracks due to crystallites. 
TABLES

Table 1. Reactivities of selected crucible materials with Al, N, $\mathrm{C}$, and $\mathrm{W}$ as reported in the literature.

\begin{tabular}{|c|c|c|c|c|}
\hline & $\mathrm{Al}$ & $\mathrm{N}$ & $\mathrm{C}$ & $\mathrm{W}$ \\
\hline $\mathrm{W}$ & $\begin{array}{l}\text { slow reaction } \\
\text { at grain } \\
\text { boundaries }\end{array}$ & $\begin{array}{l}\text { no reaction } \\
\text { with } \mathrm{N}_{2}\end{array}$ & $\begin{array}{c}\text { forms WC at } \\
1400 \text { to } 1800 \\
{ }^{\circ} \mathrm{C}[34]\end{array}$ & --- \\
\hline Mo & $\begin{array}{c}\text { forms a low } \\
\text { temperature } \\
\text { eutectic at } \\
1760^{\circ} \mathrm{C}[34]\end{array}$ & self-limited & $\begin{array}{l}\text { forms MoC at } \\
1200 \text { to } 1400 \\
{ }^{\circ} \mathrm{C} \text { [34] }\end{array}$ & $\mathrm{N} / \mathrm{A}$ \\
\hline $\mathrm{Ta}$ & $\begin{array}{c}\text { powder } \\
\text { reacts with } \\
\text { AIN and } \\
\text { forms TaN } \\
{[35]}\end{array}$ & $\begin{array}{c}\text { forms TaN at } \\
1100-1200 \\
{ }^{\circ} \mathrm{C}[34]\end{array}$ & $\begin{array}{c}\text { forms } \mathrm{TaC} \text { at } \\
1300 \text { to } 1500 \\
{ }^{\circ} \mathrm{C}[34]\end{array}$ & $\mathrm{N} / \mathrm{A}$ \\
\hline $\mathrm{C}$ & $\begin{array}{l}\text { incorporates } \\
\text { into AIN [36] }\end{array}$ & --- & --- & forms WC \\
\hline WC & $\begin{array}{c}\text { particles } \\
\text { decompose } \\
\text { in molten Al } \\
{[30]}\end{array}$ & stable in $\mathrm{N}_{2}$ & --- & --- \\
\hline $\mathrm{NbC}$ & $\begin{array}{c}\text { particles } \\
\text { decompose } \\
\text { in molten } \mathrm{Al} \\
{[30]}\end{array}$ & $\begin{array}{l}\text { converts to } \\
\text { the nitride } \\
\text { with } \\
\text { conversion } \\
<5 \%\end{array}$ & --- & $\begin{array}{l}\text { carbon from } \\
\mathrm{NbC} \text { reacts } \\
\text { with } \mathrm{W}\end{array}$ \\
\hline $\mathrm{TaC}$ & $\begin{array}{c}\text { interfacial } \\
\text { reactions } \\
\text { between } \mathrm{Al} \\
\text { and film to } \\
\text { form } \mathrm{Al}_{4} \mathrm{C}_{3} \\
\text { and } \mathrm{TaAl}_{3} \\
{[29]}\end{array}$ & $\begin{array}{l}\text { stable in } \mathrm{N}_{2} \\
\text { up to } 3315 \\
{ }^{\circ} \mathrm{C} \text { [37] }\end{array}$ & --- & $\begin{array}{c}\text { carbon from } \\
\text { TaC reacts } \\
\text { with } \mathrm{W}\end{array}$ \\
\hline TiC & $\begin{array}{c}\text { interfacial } \\
\text { reactions } \\
\text { between } \mathrm{Al} \\
\text { and film to } \\
\text { form } \mathrm{TiAl}_{3} \\
{[29]}\end{array}$ & $\begin{array}{l}\text { converts to } \\
\text { the nitride } \\
\text { between } \\
1000-1300 \\
{ }^{\circ} \mathrm{C}[38]\end{array}$ & --- & $\begin{array}{l}\text { carbon from } \\
\text { TiC reacts } \\
\text { with W }\end{array}$ \\
\hline $\mathrm{HfC}$ & $\begin{array}{c}\text { less } \\
\text { tendency to } \\
\text { react with } \mathrm{Al} \\
\text { than } \mathrm{TaC}, \\
\mathrm{NbC} \text { and } \mathrm{TiC} \\
{[31]}\end{array}$ & $\begin{array}{c}\text { the } \\
\text { maximum } \mathrm{N} \\
\text { contaminatio } \\
\mathrm{n}<1 \% \text { at } \\
2500{ }^{\circ} \mathrm{C} \text { in } 1 \\
\text { atm of } \mathrm{N}_{2} \\
{[39]}\end{array}$ & --- & $\begin{array}{c}\text { carbon from } \\
\mathrm{HfC} \text { reacts } \\
\text { with W }\end{array}$ \\
\hline $\mathrm{BN}$ & $\begin{array}{c}\text { AIN does not } \\
\text { wet or react } \\
\text { with } \mathrm{BN}\end{array}$ & --- & $\begin{array}{c}\text { reacts with } \\
\text { graphite } \\
\text { above } 2200 \\
{ }^{\circ} \mathrm{C}\end{array}$ & $\begin{array}{c}\text { reacts with W } \\
\text { above } 1100 \\
{ }^{\circ} \mathrm{C} \text { [35] }\end{array}$ \\
\hline $\mathrm{TiB}_{2}$ & $\begin{array}{c}\text { high stability } \\
\text { in Al vapor } \\
{[40]}\end{array}$ & $\begin{array}{c}\text { surface } \\
\text { reaction with } \\
\mathrm{N}_{2} \text { and forms } \\
\mathrm{TiN} \text { above } \\
1750^{\circ} \mathrm{C} \text { [41] }\end{array}$ & $\begin{array}{c}\text { interacts } \\
\text { slightly } \\
\text { (about } 1 \% \text { ) } \\
\text { at } 2200{ }^{\circ} \mathrm{C} \\
{[42]}\end{array}$ & $\begin{array}{l}\text { forms } W_{2} B \\
\text { above } 1800 \\
{ }^{\circ} \mathrm{C}[43][44]\end{array}$ \\
\hline TaN & $\begin{array}{c}\text { interfacial } \\
\text { reactions } \\
\text { between } \mathrm{Al} \\
\text { and film to } \\
\text { form } \mathrm{AIN} \text { and } \\
\mathrm{TaAl}_{3}[29]\end{array}$ & --- & $\begin{array}{l}\text { reacts with } \\
\text { graphite } \\
\text { vapor above } \\
1600^{\circ} \mathrm{C}\end{array}$ & $\mathrm{N} / \mathrm{A}$ \\
\hline $\mathrm{TiN}$ & $\begin{array}{c}\text { reacts with } \mathrm{Al} \\
\text { at } 1000^{\circ} \mathrm{C} \\
{[45] \text { and }} \\
\text { forms } \mathrm{AIN} \\
\text { and } \mathrm{TiAl}_{3}\end{array}$ & --- & $\begin{array}{c}\text { carbide } \\
\text { phase forms } \\
\text { at } 1400{ }^{\circ} \mathrm{C} \\
{[46]}\end{array}$ & $\begin{array}{c}\text { no reaction } \\
\text { [47] }\end{array}$ \\
\hline
\end{tabular}

Table 2. Presumed species present in the graphite furnace under the crystal growth condition.

\begin{tabular}{|c|c|c|}
\hline Vapor Phase & Solid Phase & $\begin{array}{c}\text { Carbide/ } \\
\text { (Carbide+Nitride) } \\
\text { at } 1700{ }^{\circ} \mathrm{C} \text { to } 2600{ }^{\circ} \mathrm{C}\end{array}$ \\
\hline $\mathrm{Al}(\mathrm{g}), \mathrm{C}(\mathrm{g}), \mathrm{N}_{2}$ & $\mathrm{AIN}(\mathrm{s}), \mathrm{C}(\mathrm{s})$ & $\mathrm{N} / \mathrm{A}$ \\
\hline $\mathrm{C}(\mathrm{g}), \mathrm{CN}(\mathrm{g}), \mathrm{N}_{2}$ & $\mathrm{C}(\mathrm{s})$ & $\mathrm{N} / \mathrm{A}$ \\
\hline $\mathrm{B}(\mathrm{g}), \mathrm{C}(\mathrm{g}), \mathrm{CN}(\mathrm{g}), \mathrm{N}_{2}$ & $\mathrm{BN}(\mathrm{s}), \mathrm{B}_{4} \mathrm{C}(\mathrm{s}), \mathrm{C}(\mathrm{s})$ & $<0.01 \%$ \\
\hline $\mathrm{Ti}(\mathrm{g}), \mathrm{C}(\mathrm{g}), \mathrm{CN}(\mathrm{g}), \mathrm{N}_{2}$ & $\mathrm{TiN}(\mathrm{s}), \mathrm{TiC}(\mathrm{s}), \mathrm{C}(\mathrm{s})$ & $96 \%$ \\
\hline $\begin{array}{c}\mathrm{Nb}(\mathrm{g}), \mathrm{C}(\mathrm{g}), \mathrm{CN}(\mathrm{g}), \\
\mathrm{N}_{2}\end{array}$ & $\mathrm{NbN}(\mathrm{s}), \mathrm{NbC}(\mathrm{s}), \mathrm{C}(\mathrm{s})$ & $96 \%$ \\
\hline $\mathrm{W}(\mathrm{g}), \mathrm{C}(\mathrm{g}), \mathrm{CN}(\mathrm{g}), \mathrm{N}_{2}$ & $\mathrm{WC}(\mathrm{s}), \mathrm{C}(\mathrm{s})$ & $\mathrm{WC} /(\mathrm{WC}+\mathrm{W}):>96 \%$ \\
\hline $\mathrm{Ta}(\mathrm{g}), \mathrm{C}(\mathrm{g}), \mathrm{CN}(\mathrm{g}), \mathrm{N}_{2}$ & $\mathrm{TaC}(\mathrm{s}), \mathrm{TaN}(\mathrm{s}), \mathrm{C}(\mathrm{s})$ & $>99 \%$ \\
\hline
\end{tabular}

